\title{
Teatro amador no Rio de Janeiro: associativismo dramático na construção da cidadania
}

\author{
Luciana Penna-Franca ${ }^{1 *}$ \\ ${ }^{1}$ Universidade Federal Fluminense, Niterói, Rio de Janeiro, Brasil
}

\section{RESUMO}

Entre 1861 e 1930, 196 associaçôes dramáticas amadoras intituladas sociedades, grêmios, clubes ou grupos atuavam no Rio de Janeiro. Este artigo pretende analisá-las como formas associativas de expressão que lutavam por algum tipo de reconhecimento, maior instrução, melhorias urbanas, sociais ou trabalhistas ou exercitavam práticas de diversão na construção e na afirmação de sua cidadania no cotidiano da capital. Espalhadas por toda a cidade, reuniam operários, funcionários públicos, militares, advogados, banqueiros do jogo do bicho; indivíduos pertencentes a diferentes grupos sociais e com os mais diversos objetivos, mas com uma prática comum: fazer e assistir teatro.

Palavras-chave: teatro amador; Rio de Janeiro; associativismo dramático; imprensa teatral; cidadania.

\section{Amateur Theatre in Rio de Janeiro: Dramatic Associativism in the Construction of Citizenship}

\begin{abstract}
Between 1861 and 1930, there were 196 active amateur dramatic associations in Rio de Janeiro, which were named societies, guilds, clubs or groups. This article intends to analyze them as associative forms of expression that struggled to obtain some sort of recognition, better schooling, urban, social or work-related improvements, or that exercised entertainment practices in the construction and affirmation of their citizenship within the daily life of the capital city. Scattered throughout the city, they were composed of blue-collar workers, public servants, soldiers, lawyers, numbers game financial controllers; individuals who were parts of different social groups and who had very distincts goals, but one common practice: to make and watch the theater.
\end{abstract}

Keywords: amateur theater; Rio de Janeiro; dramatic associativism; theatrical press; citizenship.

DOI: http://dx.doi.org/10.1590/2237-101X01903905

Artigo recebido em 21 de agosto de 2017 e aprovado para a publicaçáo em 18 de janeiro de 2018.

* Doutora pela Universidade Federal Fluminense e professora do município de Teresópolis. E-mail: lucianagremlim@gmail.com. 


\section{Teatro amador en Río de Janeiro: asociaciones dramáticas en la construcción de la ciudadanía}

\section{RESUMEN}

Entre 1861 y 1930, 196 asociaciones dramáticas amadoras denominadas sociedades, gremios, clubes o grupos actuaban en Río de Janeiro. Este artículo pretende analizarlas como formas asociativas de expresión que luchaban por algún tipo de reconocimiento, mayor instrucción, mejoras urbanas, sociales o laborales, o ejercitaban prácticas de diversión en la construcción y afirmación de su ciudadanía en el cotidiano de la capital. Esparcidas por toda la ciudad, reunían obreros, funcionarios públicos, militares, abogados, tesoreros del juego de números; individuos pertenecientes a diferentes grupos sociales y con los más diversos objetivos, pero con una práctica común: hacer y asistir al teatro.

Palabras clave: teatro amador; Río de Janeiro; asociaciones dramáticas; prensa teatral; ciudadanía.

\section{Em busca de uma cena esquecida}

As experiências de grupos dramáticos amadores, no final do século XIX e no início do $\mathrm{XX}$, são reveladoras de uma prática social de inúmeros sujeitos que ficaram "esquecidos" pela historiografia, mas que se mostraram fundamentais para novos estudos sobre história e teatro. Organizados em diversas formas associativas de expressão, lutavam por algum tipo de reconhecimento, como maior instruçáo, melhorias urbanas, sociais ou trabalhistas ou exercitavam práticas de diversão na construçáo e na afirmaçáo de sua cidadania no cotidiano da capital. Disseminados por todos os bairros do Rio de Janeiro e com associados de diferentes camadas sociais, grêmios, clubes e sociedades dramáticas eram espaços de sociabilidade e criação de vínculos e tensôes sociais, expressas em disputas pessoais ou entre agremiaçóes, que os definiam e marcavam posiçóes e posicionamentos na sociedade carioca.

O conceito de experiência é definido por Thompson como um complexo conjunto de inserçôes dos sujeitos no interior das relaçôes produtivas, porém não de forma mecânica ou direta mas, ao contrário, pela "consciência" e pela "cultura" dos agentes sociais. ${ }^{1}$ Atribuindo significados a essas relaçôes e agindo de forma imprevisível, o teatro amador é entendido como uma forma de linguagem mediadora de experiências sociais complexas, e, por isso, é uma importante maneira de intervenção e de transformação social incidindo sobre modos de pensar e de viver.

\footnotetext{
${ }^{1}$ THOMPSON, E. P. Folclore, antropologia e história social. In: NEGRO, Antonio Luigi; SILVA, Sergio (Orgs.). As peculiaridades dos ingleses e outros artigos. Campinas: Editora da Unicamp, 2001, p. 231-235.
} 
No entanto, encontrar os amadores cariocas não é uma tarefa fácil! Os críticos ou estudiosos do teatro ${ }^{2}$ contemporâneos dessa vida teatral intensa e diversificada na capital federal ao longo do século XX, que se dedicaram a contar a "história do teatro brasileiro", com os olhos voltados para a tradição teatral europeia, quase sempre a francesa, e orientados por uma concepção de história "evolutiva” e linear, construíram "fases”, definiram periodizações e registraram textos e práticas teatrais que julgaram representativas de cada "período" ou "gênero", silenciando quase completamente sobre as experiências de amadores com o teatro. Os poucos comentários e informaçôes sobre o teatro amador foram encontrados em relatos de memorialistas. ${ }^{3}$ Esse silêncio foi bastante intrigante e provocativo. Muitas vezes com base nas próprias experiências vividas no teatro, nos relatos de estrangeiros ou nos artigos escritos para jornais, esses autores recusavam a produção cênica que testemunhavam, alardeavam com frequência o que chamaram de "crise do teatro nacional" e insistiam na necessidade da formação de um "teatro nacional”.

Assim, a partir dos comentários, ainda que superficiais, dos memorialistas sobre o "teatrinho" nos subúrbios da capital e da importância dada pela imprensa da época às sociedades particulares (dedicando, muitas vezes, uma coluna permanente ao teatro amador), busco olhar mais atentamente para esses grupos. De fato, a historiografia teatral não valorizou essa maneira de atuar nos palcos da cidade e, por isso, é necessário buscar fontes espalhadas e raras para localizar essa importante prática social na cidade. Para tal, além dos memorialistas, jornais voltados aos assuntos teatrais e até mesmo produzidos pelos próprios amadores, a documentação da polícia que autorizava o funcionamento das sociedades particulares mostra-se fundamental.

Chamados de grêmios, clubes e sociedades, espalhavam-se pela capital e reuniam operários, funcionários públicos, militares, advogados, banqueiros do jogo do bicho pertencentes a diferentes grupos sociais e com os mais diversos objetivos, mas com uma prática comum: fazer e assistir teatro. $\mathrm{O}$ maior alcance das linhas de trem e o crescimento da cidade, mais ainda com as reformas de Pereira Passos no início do século, colaboraram para a dissemina-

\footnotetext{
${ }^{2}$ MARINHO, Henrique. O Theatro Brasileiro (Alguns apontamentos para sua história). Rio de Janeiro: H. Garnier, 1904; PAIXÃO, Múcio da. O Theatro no Brasil (obra póstuma). Rio de Janeiro: Brasília Editora, 1917; CACCIAGLIA, Mario. Pequena história do teatro no Brasil (quatro séculos de teatro no Brasil). São Paulo: Edusp, 1986; NUNES, Mário. 40 anos de teatro. Rio de Janeiro: SNT, 1956, v. I (1913-1920), v. II (1921-1925), v. III (1925-1930), v. IV (1931-1935); ABREU, Brício de. Esses populares tão conhecidos. Rio de Janeiro: Raposo Carneiro, 1963; SOUZA, J. Galante de. O Teatro no Brasil. Rio de Janeiro: MEC/Instituto Nacional do Livro, 1960, t. I e II.

${ }^{3}$ EDMUNDO, Luiz. [1938] O Rio de Janeiro do meu tempo. Brasília: Conselho Editorial do Senado Federal, 2003. Disponível em: www.dominiopublico.gov.br; EFEGÊ, Jota. O cabrocha (Meu companheiro de "farras"). Rio de Janeiro: Casa Leuzinger, 1931 e Meninos, eu vi. Rio de Janeiro: Funarte, Instituto Nacional de Música, Divisão de Música Popular, 1985. RIO, João do. Questão Teatral, 30 de maio de 1909. In: PEIXOTO, Níobe Abreu. João do Rio e o palco: página teatral. São Paulo: Edusp, 2009; TIGRE, Manoel Bastos. Reminiscências. A alegre roda da Colombo e algumas figuras do tempo de antigamente. Brasília: Thesaurus Editora, 1992; ABREU, Brício de. Esses populares tão desconhecidos, op. cit.; NETO, Coelho. Palestras da tarde. Rio de Janeiro: Livraria Garnier, 1911.
} 
ção dos clubes dramáticos desde a região central até os bairros mais distantes. Mais do que um tablado, muitos clubes dramáticos constituíam-se como lugares de encontro e aprendizado, tinham também biblioteca e espaços para aulas e cursos oferecidos aos associados e suas famílias. Dessa maneira, se constituíam como espaços de sociabilização e convivência entre vizinhos, imigrantes, colegas de trabalho e familiares. Algumas sociedades assumiam a função de auxílio mútuo, colaborando com os sócios em caso de doença, morte, desemprego... Outras discutiam a valorização do trabalho e podiam atuar na luta por melhores condiçóes de trabalho e de vida, inclusive, abraçando os ideais anarquistas.

De qualquer maneira, mesmo quando seus objetivos eram simplesmente a diversão e o lazer, sociedades dramáticas tornavam-se também espaços legítimos de participação e ação política que garantiam a cidadania de seus associados. O associativismo dramático, ao lado de outras formas de união e práticas sociais, colaborava na transformação do cotidiano social e urbano sendo parte do movimento mais amplo de invenção coletiva de espaços e estratégias de organização e atuação nos diferentes bairros da cidade.

No decorrer deste artigo apresento um panorama dos grupos de teatro amador disseminados por todos os bairros da capital que se transformava rapidamente nas últimas décadas do século XIX, e, particularmente, na primeira década do XX. O levantamento de dados abordados ainda pouco discutidos nos estudos teatrais procura compreender de que maneira o associativismo dramático era uma prática que estava para além dos palcos, desde as motivaçôes desses artistas até sua atuação política e social, colaborando de maneira efetiva na construção da cidadania desses sujeitos e da própria cidade.

\section{Os espaços ocupados pelos artistas amadores}

No dia 12 de agosto de 2014 foi reinaugurado o prédio da Sociedade Dramática Particular Filhos de Talma, na Rua do Propósito, na Saúde. Depois de restaurado em função das obras de revitalização da regiâo portuária do Rio de Janeiro, o local está funcionando atualmente como centro cultural. Sua primeira inauguração aconteceu em 1879 e contou com seus artistas amadores para inúmeras apresentaçôes teatrais ao longo de muitas décadas. O periódico Almanack dos Theatros, de 1910, elogia a "fama" dos seus amadores "citados com respeito" por qualquer outra sociedade e também pelo número de artistas que passaram para o teatro profissional. Apesar de apontar o "micróbio da decadência" que contaminava aquela Sociedade Dramática, o periódico comenta o fato de terem edifício próprio e "uma das mais completas bibliotecas teatrais". ${ }^{4}$ Hoje, com página no Facebook cheia de fotografias ${ }^{5}$ e depoimentos, percebemos o alcance que o clube teve (e ainda tem) na comunidade que morava nos arredores e participa-

\footnotetext{
${ }^{4}$ Almanack dos theatros. Rio de Janeiro, 1910, p. 45.

${ }^{5}$ Infelizmente, as fotografias disponibilizadas são apenas da reinauguração e alguns eventos posteriores. Das antigas, somente uma de um baile de carnaval na década de 1920 e outras sem referência de data ou qual evento.
} 
va das atividades oferecidas. A longa vida dessa sociedade, fechada ou não, funcionando por alguns períodos curtos ou nem tâo curtos assim, é surpreendente. Ainda que hoje seu funcionamento seja bastante diverso daquele no final do século XIX e no início do XX, a presença desses amadores é parte de uma importante história do teatro carioca.

Assim como os Filhos de Talma marcaram a história da capital, do bairro da Saúde e dos seus frequentadores, outras muitas associações dramáticas também constroem a história do teatro amador no Rio de Janeiro. O professor, escritor, arquivista e tradutor Escragnole Doria fez uma avaliaçáo acerca do teatro amador desse período em um artigo publicado em 1943 na Revista da Semana. Reclamando dos poucos teatros de seu tempo e das dificuldades enfrentadas por atores e mesmo a concorrência dos cinemas, o autor relembra a quantidade de clubes dramáticos amadores na capital "em tempos próximos da época atual". Entre outros exemplos, ele cita a Sociedade Particular Recreio Dramatico Riachuelense, que era uma das mais "antigas e persistentes" da capital de outrora. Segundo ele, essa sociedade foi instalada em 11 de junho de 1875, mas a inauguraçáo do teatro só teria acontecido em 2 de dezembro de 1887, apesar de já fazer apresentaçôes teatrais há mais tempo. Contando, assim, com sede e teatro próprios, essa sociedade teve vida longa, como outras que veremos ao longo deste artigo. ${ }^{6}$

A partir da documentação pesquisada e da bibliografia, encontrei o significativo número de 196 associaçóes entre 1861 e 1930. Na década de 1860, apenas quatro agremiações foram encontradas, e entre 1921 e 1930, apenas duas. Assim, em função da maior concentração dos grupos entre 1871 e 1920, sobre este recorte temporal estarão concentradas minhas atençôes. Algumas dessas associaçôes se mantêm cruzando décadas e resistindo às adversidades. Periódicos da pequena imprensa teatral, ${ }^{7}$ produzidos pelos próprios amadores ou não, pedidos de licença para funcionamento e estatutos de sociedades particulares e memorialistas constituem as fontes exploradas, que, apesar de sua grande quantidade, é esparsa e pulverizada ao longo do período abordado. Cento e seis clubes têm Dramático em seus nomes, porém outros, como o Grupo Delormista ${ }^{8}$ ou o Elite Club, ${ }^{9}$ também tinham o teatro como sua

\footnotetext{
${ }^{6}$ DORIA, Escragnole. Teatro de amadores. Revista da Semana, Rio de Janeiro, p. 19, 26 jun. 1943.

${ }^{7}$ Outros trabalhos, como a dissertação de mestrado em História do Eduardo Hipólide, $O$ teatro anarquista como prática social do movimento libertário (São Paulo e Rio de Janeiro — de 1901 a 1922) e o artigo de Marco Marques Pestana, Da Zona Sul ao Subúrbio: o mapa da festa. Por uma reconstruçáo holística do cotidiano dos trabalhadores cariocas, 1900-1920, que serão citados ao longo do artigo, utilizam a imprensa operária e comentam sobre as atividades culturais nas associaçôes de trabalhadores. O teatro é prática importante nesse meio e sempre noticiado nos periódicos. No gozo dos direitos civis: associativismo no Rio de Janeiro, 19031916, livro de Vítor Manoel Marques da Fonseca, traz importante pesquisa acerca das associaçóes de vários tipos a partir da documentaçáo da polícia encontrada no Arquivo Nacional. Por isso é certo que haja um número ainda maior de sociedades dramáticas do que as citadas aqui.

${ }^{8}$ Publicavam o periódico O Delormista: orgão consagrado ao theatro fluminense e ao grupo Delormista. $\mathrm{O}$ único exemplar é uma homenagem à atriz Aurelia Delorme.

${ }^{9}$ EDMUNDO, Luiz. O Rio de Janeiro do meu tempo, op. cit., p. 280; AZEVEDO, Arthur. O Theatro, $A$ Notícia, Rio de Janeiro, 11 jul. 1901, 12 dez. 1901, 28 dez. 1899, 15 set. 1898, 27 fev. 1902, 10 nov. 1898, 16 mar. 1899. In: NEVES, Larissa de Oliveira; LEVIN, Orna Messer (Orgs.). O Theatro, crônicas de Arthur Azevedo. Campinas: Editora Unicamp, 2009; DORIA, Escragnole. Teatros de amadores, op. cit., p. 19; Al-
} 
principal atividade. Havia ainda os clubes que se intitulavam recreativos e a prática do teatro aparecia em meio a outras atividades recreativas, como, por exemplo, a dança ou a música. Outros eram referidos como Theatro: era o caso do Theatro S. João-Particular, localizado na R. D. Anna Nery, n. 151, em Sampaio, e era administrado pelo Grupo Geraldo Fernandes - Diversôes Intimas ${ }^{10}$, ou do Nucleo Domestico Theatrinho Pires. ${ }^{11}$

O quadro a seguir apresenta a distribuição dos grupos dramáticos encontrados ao longo das décadas entre 1861 e 1930:

\section{Quadro 1. Distribuiçáo de grupos dramáticos por décadas}

\begin{tabular}{|c|c|c|}
\hline Décadas & Quantidade de clubes & Total de clubes \\
\hline $1861-1870$ & 4 & \\
\hline $1871-1880$ & 13 & \\
\hline $1881-1890$ & 62 & \multirow{2}{*}{196} \\
\hline $1891-1900$ & 13 \\
\hline $1901-1910$ & 51 & \\
\hline $1911-1920$ & 54 & \\
\hline $1921-1930$ & 2 \\
\hline Sem data & 22 & \\
\hline
\end{tabular}

Fonte: Quadro elaborado com base em informaçôes esparsas reunidas em periódicos, atas, pedidos de licença e outros documentos de grupos dramáticos depositados no Arquivo Nacional e na Biblioteca Nacional.

Alguns desses clubes aparecem em diferentes décadas (às vezes em mais de um ano), e, nesses casos, eles foram contabilizados a cada década em que apareceram. Por exemplo, o Club Dramatico Villa Isabel aparece em 1884 e 1906, havendo outros no mesmo caso. Há, no entanto, uma discrepância na década entre 1891 e 1900, onde só foram encontradas 13 associações dramáticas, enquanto na década anterior foram 62, e na posterior, 51. Em busca de uma resposta para essa queda no número de clubes, voltei às fontes que comentavam sobre eles.

A legislação até a primeira década do século XX não exigia a permissão da polícia para o funcionamento de algumas sociedades civis, como as artísticas e as recreativas, por isso

manaque d'O Theatro, ano 1, 1906; AZEVEDO, Arthur. O Badejo. In: AZEVEDO, Arthur. Teatro de Artur Azevedo. Rio de Janeiro: Funarte, 2002, v. V.

${ }^{10}$ A localização dos grupos dramáticos foi realizada com base em pesquisas a partir dos endereços de suas sedes. Porém, em alguns casos não foi possível identificar com certeza, já que existem ruas com o mesmo nome em dois ou três bairros no mesmo ano: Club Dramatico Fluminense na rua Senador Euzébio n. 236, em 1904 - Botafogo ou Mangue; Gremio Dramatico Bibi na rua do Uruguai, 22, em 1906 - Tijuca ou Guaratiba; Club Dramatico do Ouro na rua Guilhermina n. 3, em 1906 - Encantado, Penha ou Santa Cruz Cruz; Gremio Dramatico Quatro de Novembro na rua General Gurjáo n. 12, em 1906 - Caju ou Vila Militar; Theatro da Rua dos Condes, em 1906, bairro não identificado; Violeta Club, com sede na Ladeira do Barroso n. 52, em 1914 - Gamboa ou Copacabana. ${ }^{11}$ Gazeta Suburbana, ano I, n. 2, 22 dez. 1883 e ano II, n. 3, 6 jan. 1884. 
todas as informaçôes colhidas nas décadas de 1880 e 1890 são referências em diversos periódicos, em memorialistas e em pesquisadores atuais. No entanto, em 1894, o Código de Posturas, Leis, Decretos, Editais e Resoluçóes da Intendência Municipal do Distrito Federal determina a censura sobre o conteúdo das peças, envolvendo um juiz inspetor de teatro para essa licença. É possível que estivesse havendo uma adaptação dos clubes dramáticos a esses novos trâmites republicanos e mesmo uma confusão burocrática sobre essas novas determinaçôes. Uma outra hipótese é a de que os documentos tenham se perdido ou estejam em outros arquivos. O que parece inverossímil é o desaparecimento de dezenas de associaçóes nesses dez anos.

É importante lembrar que esses números foram encontrados com base em fontes e bibliografia pesquisadas, porém há outros trabalhos acerca de associaçôes culturais e recreativas e muitas outras fontes possíveis, como os jornais operários, por exemplo, que podem aumentar consideravelmente esse total.

\section{A cena amadora na Capital Federal em transformação}

Oswaldo Porto Rocha descreve o crescimento do Rio de Janeiro ${ }^{12}$ apontando a primeira tentativa de expansão com d. Joáo VI, que criou a Cidade Nova (entre os morros do atual Catumbi e o canal do Mangue). São Cristóvão e partes do Centro também se desenvolvem nesse período. $\mathrm{O}$ autor associa o desenvolvimento dos meios de transporte ao crescimento da cidade. Assim, a partir de 1840, com o aparecimento do ônibus, e 1862, com a empresa de bondes instalada por Mauá, a ocupação de bairros mais distantes se torna mais viável. Porém, é em 1872 que é inaugurada a Estrada de Ferro D. Pedro II, e dois anos depois começam as primeiras casas em Vila Isabel, que contava também com uma linha de bonde. $\mathrm{O}$ mesmo aconteceu com Copacabana, Ipanema, Leblon e Tijuca. A outra alternativa para o transporte de um número maior de pessoas era a Estrada de Ferro Central do Brasil, inaugurada em 1858. No entanto, somente em 1861 começaram os serviços regulares de transporte de passageiros. O objetivo da Estrada de Ferro, segundo Rocha, era, na verdade servir ao interland do porto da capital, transportando café para exportação e distribuindo produtos importados que chegavam ao mesmo porto.

Em 1861, existiam apenas cinco estaçóes: freguesia de Santana (terminal), Engenho Velho, São Cristóvão, Inhaúma e Irajá. O bairro de Cascadura recebe o trem a partir de 1870, o Engenho de Dentro inaugura sua estação em 1873, o Méier em 1889, Madureira em 1891 e, em 1907, é inaugurada uma quarta linha que vai até Deodoro, o que dinamiza o tráfego de trens expressos e rápidos. Na passagem do século XIX para o XX mais três estradas de ferro se juntaram à

\footnotetext{
${ }^{12}$ ROCHA, Oswaldo Porto. A era das demoliçôes: cidade do Rio de Janeiro: 1870-1920. Rio de Janeiro: Secretaria Municipal de Cultura, Dep. Geral de Doc. e Inf. Cultural, Divisão de Editoração, 1995.
} 
Estrada de Ferro Central do Brasil: The Leopoldina Railway, antiga Estrada de Ferro do Norte, a Estrada de Ferro Rio D'Ouro e a Estrada de Ferro Melhoramentos do Brasil. Desse modo, a expansão dos bondes e trens possibilita a ocupação dos bairros das zonas norte e sul e, consequentemente, aumenta a necessidade de serviços, comércio e opções de lazer nessas vizinhanças.

Mais uma razão para esse deslocamento populacional para os bairros mais distantes ou a ocupação dos morros mais próximos favorecendo o crescimento das favelas no Rio de Janeiro foram as reformas de remodelação do Centro impostas pela administração de Pereira Passos, associado ao governo de Rodrigues Alves. Marco Marques Pestana comenta o impacto da chegada da estrada de ferro na freguesia de Inhaúma, que no final do império tinha seis estaçóes: Cascadura, Venda Grande (Engenho Novo), Engenho de Dentro, Piedade, Cupertino e Encantado. O aumento do número de habitantes desse distrito entre 1890 e 1906, segundo o autor, foi de 17.448 para 67.478 , "um crescimento de $293 \%$ em contraste com a média de $55 \%$ da cidade como um todo". Além do aumento dos horários de trens que chegavam ao subúrbio, entre 1900 e 1910, que passou de 63 para 202. ${ }^{13}$

Entretanto, apesar do aumento da população suburbana em função das moradias a preços mais acessíveis e do acesso a esses bairros facilitado pelas linhas de trem, o historiador Cláudio Batalha afirma que as áreas centrais menos atingidas pela reforma urbana de Pereira Passos mantiveram um crescimento populacional, ainda que menor do que outras áreas da capital. Mesmo que as moradias tivessem condiçóes cada vez mais precárias, a oferta de trabalho era grande, e estar próximo ao local de trabalho ainda era um atrativo.

$\mathrm{O}$ autor afirma que esses fenômenos - o crescimento populacional nos subúrbios, na região central e nas favelas nos morros - não são excludentes e podem ocorrer simultaneamente. ${ }^{14}$ De fato, apesar do aparecimento de associaçóes dramáticas em inúmeros bairros mais distantes a partir da primeira década do século XX e mais ainda da segunda, há uma maior concentração dessas agremiaçôes na região central e em seus arredores por todo o período analisado, e, ainda, um aumento significativo entre 1901 e 1920.

Em sua análise sobre associaçóes operárias, Batalha valoriza ainda o Centro como "lócus privilegiado da política", e o fato de essas sociedades terem sede própria e um endereço permanente era extremamente prestigioso, demonstrando "solidez e uma tradição consolidada". Assim, o endereço da sede significava uma "busca a inserção no espaço privilegiado da política que é o centro da cidade e, de forma inseparável, a respeitabilidade das sociedades operárias". O autor diferencia essas associações operárias que eram logradouros comerciais das sociedades carnavalescas e recreativas que forneciam

\footnotetext{
${ }^{13}$ PESTANA, Marco Marques. Da zona sul ao subúrbio: o mapa da festa. Por uma reconstrução holística do cotidiano dos trabalhadores cariocas, 1900-1920. Revista Mundos do Trabalho, v. 2, n. 4, ago./dez. 2010, p. 251. ${ }^{14}$ BATALHA, Claudio Henrique de Moraes. A geografia associativa: associaçóes operárias, protesto e espaço urbano no Rio de Janeiro da Primeira República. In: AZEVEDO, Elciene; CANO, Jefferson; CUNHA, Maria Clementina Pereira; CHALHOUB, Sidney (Orgs.). Trabalhadores na cidade: cotidiano e cultura no Rio de Janeiro e em São Paulo, séculos XIX e XX. Campinas: Editora da Unicamp, 2009, p. 253.
} 
um endereço apenas para fins de registro e, por isso, podia ser a casa de algum associado ou mesmo um botequim. ${ }^{15}$

No caso das sociedades dramáticas, encontramos 35 agremiações na regiâo do Centro, onde incluí Cidade Nova, Saúde e Santana, entre as décadas de 1861 e 1920. Dessas, três eram grupos dramáticos libertários, Teatro Livre, Primeiro de Maio e Anti-clerical. Lá também estava o Centro Galego, conhecido por ser palco de peças anarquistas. Todas as outras localizadas na região não deixam clara sua opção política. Parece possível que algumas das associaçôes dramáticas também optassem por um endereço na região central da capital em função de ser um "lócus privilegiado da política", outras, por estarem próximas de suas moradias ou seus locais de trabalho.

Apesar de haver casos de clubes dramáticos que se organizavam nas casas dos sócios ou que usavam outros espaços para suas apresentaçóes, muitos tinham sua própria sede, que podia incluir a sala de teatro, uma biblioteca, um espaço para encontros sociais e ainda aqueles que montavam escolas para os associados e suas famílias. Havia ainda os que produziam os próprios periódicos. Naturalmente esses espaços demandavam mais recursos para sua construção e manutenção, indicando as diferenças sociais entre os diversos grupos de amadores.

Para facilitar a visualização da distribuição das associações dramáticas na cidade, montei um quadro organizando-as por bairros e décadas.

Quadro 2. Distribuiçáo de grupos dramáticos por bairro e década

\begin{tabular}{|c|c|c|c|c|c|c|c|c|}
\hline Bairros & $\mathbf{1 8 6 1 -}$ & $\mathbf{1 8 7 1 -}$ & $\mathbf{1 8 8 1 -}$ & $\mathbf{1 8 9 1 -}$ & $\mathbf{1 9 0 1 -}$ & $\mathbf{1 9 1 1 -}$ & $\mathbf{1 9 2 1 -}$ & $\begin{array}{c}\text { Sem } \\
\text { data }\end{array}$ \\
\hline Centro & 1 & 2 & 5 & 2 & 13 & 12 & & \\
\hline Riachuelo & & 2 & 3 & 1 & 1 & 1 & & \\
\hline São Cristóvão & & 1 & 4 & 1 & 2 & 3 & & \\
\hline Todos os Santos & & & & & & 2 & & 1 \\
\hline Engenho Novo & & 1 & 3 & & 3 & & & \\
\hline Praia Vermelha & & 1 & & & & & & \\
\hline Cantagalo & & 1 & & & & & & \\
\hline Cascadura & & & 1 & & 1 & 1 & & \\
\hline Vila Isabel & & & 2 & & 2 & & & \\
\hline Engenho de Dentro & & & 1 & 1 & & 2 & & 1 \\
\hline Pilares & & & 1 & & & & & \\
\hline Inhaúma & & & 1 & & 1 & 2 & & \\
\hline São Francisco Xavier & & & 1 & & & & & \\
\hline Botafogo & & & & 1 & 1 & 2 & & 3 \\
\hline Tijuca & & & & 1 & 1 & 1 & & 1 \\
\hline
\end{tabular}

\footnotetext{
${ }^{15}$ Ibidem, p. 260-265.
} 


\begin{tabular}{|c|c|c|c|c|c|c|c|c|}
\hline Bairros & $\begin{array}{l}1861- \\
1870\end{array}$ & $\begin{array}{l}1871- \\
1880\end{array}$ & $\begin{array}{l}1881- \\
1890\end{array}$ & $\begin{array}{l}1891- \\
1900\end{array}$ & $\begin{array}{c}1901- \\
1910\end{array}$ & $\begin{array}{l}1911- \\
1920\end{array}$ & $\begin{array}{l}1921- \\
1930\end{array}$ & $\begin{array}{l}\text { Sem } \\
\text { data }\end{array}$ \\
\hline Engenho Velho & & & & 1 & & & & \\
\hline São Domingos & & & & 2 & & & & \\
\hline Ilha do Governador & & & & & 2 & 1 & & \\
\hline Realengo & & & & & 1 & 1 & & \\
\hline Méier & & & & & 2 & 1 & & \\
\hline Piedade & & & & & 2 & & & \\
\hline Sampaio & & & & & 1 & & & \\
\hline Catete & & & & & 1 & & & \\
\hline Andaraí & & & & & 1 & 1 & & 2 \\
\hline Jacarepaguá & & & & & & 2 & & \\
\hline Campo dos Cardosos & & & & & & 1 & & \\
\hline Olaria & & & & & & 1 & & \\
\hline Ipanema & & & & & & 1 & & \\
\hline Rio Comprido & & & & & & 1 & & \\
\hline Ramos & & & & & 1 & 1 & & \\
\hline Santa Teresa & & & & & & 1 & & 1 \\
\hline Santa Cruz & & & & & & 2 & & \\
\hline Cachambi & & & & & & 1 & & \\
\hline Estácio de Sá & & & & & & 1 & & \\
\hline Pedregulho & & & & & & 1 & & \\
\hline Cavalcante & & & & & & & 1 & \\
\hline Catumbi & & & & & & & & 2 \\
\hline Laranjeiras & & & & & & & & 1 \\
\hline Gávea & & & & & 1 & 2 & & 2 \\
\hline Flamengo & & & & & & & & 1 \\
\hline Sem endereço & 2 & 6 & 31 & 3 & 10 & 6 & 1 & 6 \\
\hline Em dúvida ${ }^{16}$ & & & & & 5 & 1 & & \\
\hline
\end{tabular}

Fonte: Quadro elaborado com base em informaçôes esparsas reunidas em periódicos, atas, pedidos de licença e outros documentos de grupos dramáticos depositados no Arquivo Nacional e na Biblioteca Nacional.

\footnotetext{
${ }^{16}$ A localização dos grupos dramáticos foi realizada com base em pesquisas a partir dos endereços de suas sedes. Porém, em alguns casos não foi possível identificar com certeza, já que existem ruas com o mesmo nome em dois ou três bairros no mesmo ano: Club Dramatico Fluminense na rua Senador Euzébio n. 236, em 1904 - Botafogo ou Mangue; Gremio Dramatico Bibi na rua do Uruguai, 22, em 1906 - Tijuca ou Guaratiba; Club Dramatico do Ouro na rua Guilhermina n. 3, em 1906 - Encantado, Penha ou Santa Cruz; Gremio Dramatico Quatro de Novembro na rua General Gurjão n. 12, em 1906 - Caju ou Vila Militar; Theatro da Rua dos Condes, em 1906, bairro náo identificado; Violeta Club, com sede na Ladeira do Barroso n. 52, em 1914 - Gamboa ou Copacabana.
} 
Mesmo com a expansão dos meios de transporte, era comum, nas críticas e nas crônicas sobre as peças teatrais que aconteciam nesses clubes, reclamaçóes sobre a quantidade de bondes e seus horários. Em junho de 1882, O Scenario publicou uma crítica sobre a récita proporcionada pela Sociedade Gremio Dramatico Familiar S. João Baptista naquele mês e, apesar dos elogios aos amadores, pede aos diretores "a útil medida de obter das companhias Villa Isabel e Cachamby" um "maior número de bondes especiais para a Corte, a fim de que os moradores da cidade possam ir apreciar os seus divertimentos, sem grande dispêndio, como ora acontece". ${ }^{17} \mathrm{O}$ teatrólogo e crítico teatral Arthur Azevedo demonstra sua má vontade em assistir a um espetáculo no Riachuelo, mesmo tendo sido "pessoalmente convidado por uma comissão daquele clube" — Club Riachuelense — , enfatizando: "da praça da República ou do Largo do Machado para cima, o teatro não me seduz" ${ }^{18}$ Essa, porém, não era uma desculpa para não assistir peças representadas por amadores, haja visto o número enorme de clubes na região central da capital.

Os nomes de alguns clubes podiam revelar uma identidade local demonstrando seu orgulho por pertencer àquele bairro, como nos casos do Gremio Dramatico do Meyer, da Sociedade Particular Recreio Dramatico Riachuelense, da Sociedade Progressista Recreativa e Muzical de Villa Santa Thereza, do Theatro Club Boulevard de Villa Izabel, da Sociedade Recreativa Familiar Bohemios de Botafogo, da Sociedade Dramatica e Musical do Engenho de Dentro e do Club da Gavea, entre muitas outras.

Para os sócios dessas agremiaçóes, no entanto, a distância, o custo e a precariedade dos transportes e o tempo gasto de casa até o seu grêmio podiam ser fatores importantes para sua filiação, afinal não apenas tinham obrigaçóes de comparecer aos ensaios teatrais como também frequentavam esses espaços para leitura nas suas bibliotecas ou participavam de aulas e cursos oferecidos. Mais do que apenas um palco ou uma oportunidade para diversão e lazer, os clubes dramáticos eram espaços de sociabilização e convivência entre vizinhos, colegas de trabalho e familiares.

\section{Por que e para que fazer teatro? Ação política e construção da cidadania}

O historiador Uassyr de Siqueira afirma que as associaçóes de lazer para trabalhadores paulistanos correspondiam às suas necessidades cotidianas e pretendiam fortalecer os "laços de congraçamento e de igualdade entre seus membros”. No entanto, ressalta as diferenças entre os associados e que se organizavam em torno da valorização do trabalho, desempenhando,

\footnotetext{
${ }^{17}$ O Scenario: periodico do Club Familiar Gymnasio da Juventude. Rio de Janeiro, ano 2, n. 7, junho de 1882.

${ }^{18}$ AZEVEDO, Arthur. O Theatro, A Notícia, Rio de Janeiro, 28 abr. 1904. In: NEVES, Larissa de Oliveira Neves; LEVIN, Orna Messer (Orgs.). O Theatro, crônicas de Arthur Azevedo, op. cit.
} 
inclusive, outras funçôes como, por exemplo, auxílio mútuo. ${ }^{19}$ Essa prática acontecia também no Rio de Janeiro, como no caso da Sociedade Estudantina Dramatica Luzo-Brasileira, que estabelecia entre seus fins a criação "quando as posses da sociedade o permitirem" de uma pensão para seus associados que tivessem enfermos, além de um auxílio funeral. ${ }^{20}$

Para além da função de auxílio mútuo e valorização do trabalho, Leonardo Affonso de Miranda Pereira entende que esse associativismo era mesmo uma forma de participação e ação política que garantia sua cidadania. Através do Club Dançante Familiar Anjos da Meia-noite, o historiador rebate os argumentos de José Murilo de Carvalho acerca da exclusão dos trabalhadores da participação na política, manifestando-se apenas por mecanismos à margem do sistema político, como revoltas e greves. $\mathrm{O}$ clube dançante referido por Pereira foi criado na primeira década do século XX na regiáo portuária da capital, no bairro da Saúde, habitado em sua maioria por negros e mestiços. O clube fora fechado pela polícia acusado de promover desordem pública em dias de baile. Para garantir o direito de realizar bailes e outras atividades recreativas, os sócios do Anjos da Meia-noite requereram, através de um advogado, um habeas corpus no Supremo Tribunal Federal. Além de ser uma sociedade recreativa, sem fins políticos, e composta por trabalhadores de baixa renda, causou surpresa um processo aberto por uma sociedade civil. Mesmo tendo sido negado o pedido de habeas corpus, a história do Anjos da Meia-noite revela o grau de politização e de mobilização dos seus associados, demonstrando que ainda que seus objetivos fossem o lazer e a diversão, não estavam à margem da política, muito pelo contrário, comprovam que essas associaçôes eram formas de definir seu lugar em uma República recém-formada e atuar e transformar o cotidiano. $^{21}$

Do mesmo modo, as sociedades dramáticas de amadores precisavam da autorização da polícia para funcionar e, por meio das representaçóes teatrais, da oferta de cursos e espaços de leitura e convivência, possibilitando diálogos e debates acerca dos mais variados assuntos, assumiam posiçóes e travavam embates que ultrapassavam as próprias sedes e buscavam espaços nas ruas da cidade. Assim, essas associaçóes recreativas, culturais ou dramáticas constituíam espaços importantes de construção e afirmação da cidadania.

Mesmo tratando apenas de clubes dramáticos, havia profundas diferenças entre eles, sendo possível dividi-los em diversas categorias a partir de sua composição social, de seus objetivos, de suas estruturas físicas, de seus repertórios etc. Para os operários, o teatro podia ser uma prática de sua militância política, divulgando os ideais anarquistas e conscientizan-

\footnotetext{
${ }^{19}$ SIQUEIRA, Uassyr de. Clubes recreativos: organização para o lazer. In: AZEVEDO, Elciene; CANO, Jefferson, CUNHA, Maria Clementina Pereira; CHALHOUB, Sidney (Orgs.). Trabalhadores na cidade: cotidiano e cultura no Rio de Janeiro e em São Paulo, séculos XIX e XX. Campinas: Editora da Unicamp, 2009, p. 272. ${ }^{20}$ Estatutos da Sociedade Estudantina Dramatica Luzo-Brasileira. Abril de 1913. Arquivo Nacional. Cx. GIFI 6C 479.

${ }^{21}$ PEREIRA, Leonardo Affonso de Miranda. Os Anjos da Meia-noite: trabalhadores, lazer e direitos no Rio de Janeiro da Primeira República. Tempo, v. 19, n. 35, p. 97-116, 2013.
} 
do os trabalhadores de sua situação, ou apenas pura diversão. Nos estatutos dos grupos lusitanos e espanhóis fica clara a preocupação com suas origens e a preservação de sua cultura em um novo país. Não obstante, para além de uma identidade nacional, são os costumes, as experiências e vivências em comum no Brasil que os une com mais força. E ainda uma preocupação de grupos médios e das elites com o chamado "teatro de qualidade" por alguns intelectuais da época. ${ }^{22}$

Encontrei ainda alguns nomes de clubes dramáticos que indicam um teatro praticado por grupos afrodescendentes - Grêmio Dramático de Pretos, Grêmio Dramático Familiar Treze de Maio, Club Vasques, Club Dramático Xisto Bahia —, porém, a ausência de documentos específicos desses grupos não me permitiu até o momento uma análise mais aprofundada desse espaço de atuação amadorística. Os registros localizados sobre a atuação de um teatro negro começam na década de 1920 e náo se encaixam na categoria de amadores - como, por exemplo, a Companhia Negra de Revistas, que estreou em 31 de julho de 1926, com as peças Tudo preto, Preto e branco, Carvão nacional, Na penumbra e Café torrado. Essa companhia contou temporariamente com o conhecido ator negro De Chocolat, que depois fundou a Ba-ta-clan Preta. ${ }^{23}$

Orlando de Barros afirma que essa companhia teria sido a primeira companhia negra de revistas, mas que houve outras amadoras anteriormente. ${ }^{24}$ No entanto, não aponta os registros para essa constatação. Segundo esse autor, De Chocolat teria se apresentado em "teatrinhos" nos primeiros tempos de sua carreira, ficando conhecido pelo seu "primeiro nome artístico, Jocanfer, composto pelas primeiras sílabas de seu nome", além de representaçôes em "teatrinhos ao ar livre, como os do Passeio Público e da Velha Guarda". ${ }^{25}$ No entanto, não era parte de um grupo dramático amador que se denominasse na categoria como teatro negro.

Vale mencionar aqui que, dentre os estatutos localizados, apenas um único grupo proibia os sócios "de cor preta" de participar. Era o Gremio Recreativo de Ramos, que não era exclusivamente dramático, mas pretendia criar um grupo dramático e outro musical. ${ }^{26} \mathrm{~A}$ especificidade do artigo $2^{\circ}$ demonstra que outros clubes talvez admitissem negros, ainda que não fossem exclusivamente - ou talvez sim, mas sem constar nos estatutos — formados por "pessoas de cor preta". A esse respeito, Vitor Manoel Marques da Fonseca comenta que a maior parte dos estatutos das sociedades civis não

\footnotetext{
${ }^{22}$ A título de ilustração darei alguns exemplos dessas categorias. Entre os grupos de teatro amador anarquista, encontramos o Grupo Dramatico Teatro Social, Os Libertários, Pensamento e Ação, Teatro Livre, Anticlerical etc; grupos de imigrantes: Centro Galego, Lusitano Club, Recreio Dramatico da Juventude Portugueza, Centro Catalâ, Sociedade Estudantina Dramatica Luzo-Brasileira etc; entre as elites e os grupos médios, podemos citar o Club Fluminense, Gremio Dramatico Furtado Coelho, Inhaumense Club, Elite Club, Club Dramatico Alumnos de Minerva etc.

${ }^{23}$ BARROS, Orlando de. Coraçôes de Chocolat: a história da Companhia Negra de Revistas (1926-27). Rio de Janeiro: Livre Expressão, 2005, p. 14-16.

${ }^{24}$ Ibidem, p. 68.

${ }^{25}$ Ibidem, p. 47-48.

${ }^{26}$ Estatutos do Gremio Recreativo de Ramos. Junho de 1914. Arquivo Nacional. Cx. IJ6 595.
} 
estabelecia "distinçóes com base de cor ou crença religiosa”. O que havia era a questão da nacionalidade, já mencionada. ${ }^{27}$ No entanto, a partir da localização geográfica dos grêmios dramáticos, em alguns casos, pode ser possível perceber a(s) origem(s) étnica(s) dos associados, visto o exemplo dado por Pereira acerca do Club Dançante Familiar Anjos da Meia-noite, no bairro da Saúde.

A origem nacional é abordada pelo próprio Leonardo Affonso Pereira em outro artigo intitulado "Do Congo ao Tango: associativismo, lazer e identidades entre os afro-portenhos na segunda metade do século XIX”, no qual, a partir de um desentendimento entre dois grupos proprietários de um terreno em Buenos Aires, o autor analisa o associativismo afro-portenho e a questão de sua origem comum. Em uma comparação com outra sociedade também com a mesma origem nacional — no caso, a "Nação Conga" — no Rio de Janeiro, embora guardando as devidas especificidades e contextos histórico e geográfico, Pereira analisa esse associativismo entre trabalhadores que tinham no mutualismo seu fundamento principal. No entanto, apesar do reconhecimento de uma origem comum, o que de fato embasava a identidade daqueles grupos era "o compartilhamento de costumes e experiências vividas na região do Prata" ${ }^{28}$

Enfatizando a imensa quantidade de associaçóes de afrodescendentes na capital vizinha ao Brasil, o historiador as define como "forma privilegiada de exercício dos direitos civis e políticos dos seus membros". ${ }^{29}$ Em quaisquer dessas associaçóes, porém, esses são espaços de sociabilidade e solidariedades, mas também de tensóes e conflitos. No caso das sociedades dramáticas de amadores do Rio de Janeiro, o teatro se constituía uma prática central da experiência desses associados e o lazer era, assim, uma forma legítima de organização, não impedindo outras e diferentes atuaçóes políticas na sociedade.

Nesse sentido, outras associaçóes podiam ser encontradas nos diversos bairros espalhados pela cidade. Ainda segundo Leonardo Affonso Pereira, para "lidar com as identidades e culturas de base africana constituídas no contexto da diáspora", os afrodescendentes se organizavam em "espaços extraoficiais, como as irmandades religiosas ou as festas", 30 como a Festa da Penha e o carnaval.

No mesmo caminho, Martha Abreu analisa a obra de Dudu das Neves como uma possibilidade de articulação, por meio de lundus e sambas, para se pensar a ascensão dos negros no mundo musical no período pós-abolição, sendo a música uma "eficaz estratégia de luta dessa população no Brasil", além de "forte indício de que o campo musical abria possibilidades de escolha e expressão para os artistas que dialogavam com a realidade social e política de seu tempo" ${ }^{31}$ Desse modo, diferentes linguagens e formas de expressão artísticas foram usadas para fazer política e lutar por transformaçôes sociais.

\footnotetext{
${ }^{27}$ FONSECA, Vitor Manoel Marques da. No gozo dos direitos civis: associativismo no Rio de Janeiro, 19031916. Rio de Janeiro: Arquivo Nacional/Niterói: Muiraquitã, 2008, p. 129.

${ }^{28}$ PEREIRA, Leonardo Affonso de Miranda. Do Congo ao tango: associativismo, lazer e identidades entre os afro-portenhos na segunda metade do século XIX. Revista Mundos do Trabalho, v. 3, n. 6, p. 31-35, jul./ dez. 2011.

${ }^{29}$ Ibidem, p. 36.

${ }^{30}$ Ibidem, p. 51.

${ }^{31}$ ABREU, Martha. O "crioulo Dudu”: participação política e identidade negra nas histórias de um músico cantor (1890-1920). Topoi, v. 11, n. 20, p. 93, jan./jun. 2010.
} 
Em outro artigo escrito a quatro mãos com a historiadora Andrea Marzano acerca do ator Vasques e do próprio músico Dudu das Neves, as autoras analisam a dimensão política do fazer artístico e ressaltam:

E ao fazer política na arte, defenderam direitos, afirmaram sua liberdade de pensamento, divulgaram versōes de acontecimentos e lutaram por transformaçôes sociais, como a Abolição. Também falaram de eleiçóes, criaram heróis e pensaram o Brasil e os brasileiros. Na prática, criaram e foram criados por importantes canais de comunicação e expressão, como o teatro e música. A política e a nação, mesmo a oficial, lhes interessavam e diziam respeito. Com o seu público, interferiram na história e deixaram de ser meros espectadores do destino que as elites políticas queriam lhes impor.

Por todos esses motivos, ampliaram as possibilidades da cidadania e incluíram-se de alguma forma na República do Brasil. ${ }^{32}$

Nesse artigo, Marzano analisa uma carta que Vasques escreveu para o presidente Floriano Peixoto, em 1892, além de publicaçóes e atuaçóes no palco, e como, por meio de sua negação da política — o ator se definia "um homem sem política" —, a abordava e atuava politicamente. As peças escritas por jovens literatos, a partir do movimento realista, "serviam como veículos para a defesa de seus projetos políticos e sociais". ${ }^{33}$ A historiadora destaca ainda "a preocupação de Vasques com a coesão da classe artística que remete, uma vez mais, ao debate sobre as especificidades das associaçôes no Brasil". ${ }^{34} \mathrm{Na}$ verdade, as duas autoras travam, através da música de Dudu das Neves e do teatro de Vasques, um debate acerca da cidadania, combatendo as afirmaçóes de José Murilo de Carvalho sobre a "recusa do exercício da cidadania por meio dos mecanismos institucionais de participação política, que teriam no voto sua expressão mais acabada”. Brincando com palavras da época que marcaram algumas peças teatrais, como "tribofe" e "bilontra", elas afirmam:

Para Carvalho, o maior tribofe dos bilontras da República talvez fosse mesmo a busca do favorecimento pessoal. O espírito organizativo, base importante de exercício da cidadania para o autor, passaria ao largo da política institucional, só se fazendo sentir em ocasióes festivas, associaçôes religiosas e de ajuda mútua. ${ }^{35}$

\footnotetext{
${ }^{32}$ ABREU, Martha Campos; MARZANO, Andrea Barbosa. Entre palcos e músicas: caminhos de cidadania no início da República. In: CARVALHO, José Murilo; NEVES, Lúcia Maria Bastos Pereira das (Orgs.). Repensando o Brasil do Oitocentos: cidadania, política e liberdade. Rio de Janeiro: Civilização Brasileira, 2009, p. 145.

${ }^{33}$ Ibidem, p. 129.

${ }^{34}$ Ibidem, p. 133.

${ }^{35}$ Ibidem, p. 124-125.
} 
Os próprios amadores do Club Dramatico Alumnos de Minerva confirmam essa atuação e a importância de unir-se em torno de um objetivo comum. Os sócios desse clube publicavam um jornal, $O$ Paladino, e no expediente do dia 6 de agosto de 1881, esclarecem sua visão acerca da utilidade moral e material das "sociedades recreativas". Segundo Assis Vieira, redator que assina a coluna, não haveria "o menor ponto de comunicação" entre as "classes" se "não houvesse um pretexto pelo qual se reunissem na partilha de interesses comuns". Assegurando que as subdivisóes relativas às nacionalidades seriam ainda mais inevitáveis, o jornalista afirma que somente a "união" pode levar ao "triunfo", e completa:

Hoje, à luz da ciência e da consciência, está evidentemente provado que todos os homens são irmãos, que todas as profissóes são honrosas e necessárias, e que do equilíbrio existente entre as diversas classes e da confraternização entre as várias nacionalidades é que há de romper o progresso da humanindade nas suas mais esplêndidas manifestações.

Assim, pois, se às sociedades, sob o ponto de vista político, devem os povos tão assinalados benefícios, não é menos benéfica e digna de aplausos a influência exercida por esses grupos que emergem do seu seio, os quais, coletivando-se para um fim qualquer, vão espalhando em torno de si uns a instrução, outros a caridade, e muitos, finalmente, como o nosso, oferecendo a diversão e a alegria em inocentes folguedos e familiar convivência, onde todas as classes e nacionalidades se confundem e se consagram nos amplexos da mais sincera igualdade. ${ }^{36}$

Fosse por meio da instrução, da caridade ou da diversão, as sociedades recreativas, que reuniam indivíduos com objetivos em comum, eram espaços, segundo o jornalista, onde prevalecia a igualdade, sem distinção de profissão ou nacionalidade. E ainda valoriza o papel dessas agremiaçóes na sociedade:

A mocidade, por sua vez, compreendendo a utilidade da ideia, cumpriu com o seu dever, tratando de desenvolvê-la e ampliá-la — construíram-se edifícios apropriados, criando-se aulas onde empregam o tempo que lhes sobra dos labores cotidianos aqueles que desejam aperfeiçoar e completar a sua educação física e moral; hoje as sociedades recreativas erguem-se como um eloquente testemunho do quanto lhes devem o progresso material deste país e o desenvolvimento intelectual desta população.

Semelhante resultado enche de nobre e justo orgulho aqueles que contribuem com os seus esforços e sacrifícios para a existência dessas sociedades, porque se moralizar — ensinando é um importante serviço prestado às classes populares, não tem menos direito ao reconhecimento e à gratidão dessas mesmas classes os que se propoem civilizar — recreando. ${ }^{37}$

\footnotetext{
${ }^{36}$ O Paladino: orgão do Club D. Alumnos de Minerva. Rio de Janeiro, ano I, n. 3, 6 ago. 1881, p. 1. ${ }^{37}$ Idem.
} 
Assis Vieira compreende, então, a atuaçáo das sociedades recreativas na construção de uma cidadania e na própria transformação do cotidiano pela uniáo em torno de um objetivo comum e também pela criação de aulas nas sedes dos clubes. E finaliza afirmando: "As sociedades recreativas são o marco miliário plantado na senda do progresso moral e material deste país."

As associações dramáticas de amadores comprovam essa capacidade organizacional dos sujeitos sociais que optavam por unir-se em torno do teatro como atividade de lazer. Para além do texto teatral, os clubes dramáticos tinham um alcance muito maior do que apenas o palco, atuando como elemento aglutinador de moradores de um mesmo bairro, trabalhadores de uma mesma fábrica, estrangeiros de uma mesma origem ou mesmo misturando os mais diferentes grupos, que, fortalecendo seus laços identitários, acabavam por encontrar formas de atuação na cidade que estavam para além do lúdico.

Um outro modo de associativismo é objeto da pesquisa de Laura Antunes Maciel, que se dedica a grupos populares constituídos em grêmios, clubes ou centros literários, que "se reuniam para ler e discutir livros, recitar poemas, debater teses, discursar, editar e dar divulgação à produção intelectual de homens e mulheres sem outros meios de intervenção no debate público sobre literatura". Na luta contra o analfabetismo, essas sociedades eram compostas por "professores primários, contadores, pequenos funcionários públicos, empregados do comércio ou de ferrovias, bacharéis em Direito, que se reconheciam como parte do povo, se apresentavam como poetas, escritores ou intelectuais, e atuaram como autores e editores".

A autora ressalta, no entanto, que apesar de "uma identidade de objetivos e interesses" na luta contra a "centralização literária" ou o "bairrismo literário", os grupos que as constituíam eram caracterizados por uma heterogeneidade social e se encontravam na "busca por autonomia em relação aos espaços institucionais das letras "oficiais" e uma educação mais democratizada. ${ }^{38}$

Leandro Climaco Mendonça também dedicou sua investigação ao associativismo ligado à produção de periódicos em bairros suburbanos da capital. O historiador aponta a importância desses jornais como espaços para "debate das necessidades e demandas dos subúrbios", além de criar "possibilidades de construçáo de articulaçôes entre os jornalistas e outros segmentos da sociedade". ${ }^{39}$

Conviviam, entâo, diversos modos de associativismo na capital que, apesar de suas diferentes propostas, atuavam de maneira efetiva na transformação do cotidiano e demonstravam uma atuação política, mesmo sem se definir como tal, colaborando na construção da cidadania e do próprio país.

\footnotetext{
${ }^{38}$ MACIEL, Laura Antunes. Cultura letrada, intelectuais e memórias populares. In: ENGEL, Magali Gouveia; CORREAA, Maria Letícia; SANTOS, Ricardo Augusto dos (Orgs). Os intelectuais e a cidade: séculos XIX e XX. Rio de Janeiro: Contra Capa, 2012, p. 58-60.

${ }^{39}$ MENDONÇA, Leandro Climaco Almeida de Melo. Nas margens: experiências de suburbanos com periodismo no Rio de Janeiro, 1880-1920. Dissertação (mestrado em História) — Programa de Pós-graduação em História, Universidade Federal Fluminense, Niterói, 2011, p. 131.
} 


\section{Ação social e cultura em palcos amadores}

A partir do quadro aqui apresentado, deve-se observar com atenção os espetáculos beneficentes oferecidos pelas sociedades dramáticas particulares, que podiam ser para "benefícios sociais e individuais", ${ }^{40}$ como no caso do Club Riachuelense, que fez uma récita em 30 de outubro de 1882 para alforriar o escravo Narciso, porteiro e guarda do clube. ${ }^{41}$ A peça Hele$n a$ voltou a ser representada pelo Elite Club em 1899, em benefício de quatro órfãos deixados por Portugal, "camarada" de Arthur Azevedo. O presidente do clube, Teixeira Júnior, arcou com as despesas do espetáculo, e as amadoras venderam os bilhetes. ${ }^{42}$

Ou também em benefício de um associado ou amador em necessidade, como na récita inaugural organizada pelo Grupo dos Ethereos do Gremio Celeste, que beneficiou a atriz Marietta Borges ${ }^{43}$ Para alguns órfão e escravos, foi oferecido o drama José do Telhado pela S. B. Amor e Caridade..$^{44}$ Também o Club Dramatico Alumnos de Minerva ofereceu o drama em quatro atos $O$ órfáo e o mendigo e a comédia Os dois calvos, representados no teatro S. Pedro, a "um militar cego por ferimentos recebidos em campanha". ${ }^{45}$ A mesma peça foi apresentada seis meses depois no teatro do próprio clube.

\section{Figura 1. Programa do Club Dramatico Alumnos de Minerva para a soirée de 10 de setembro de 1881}

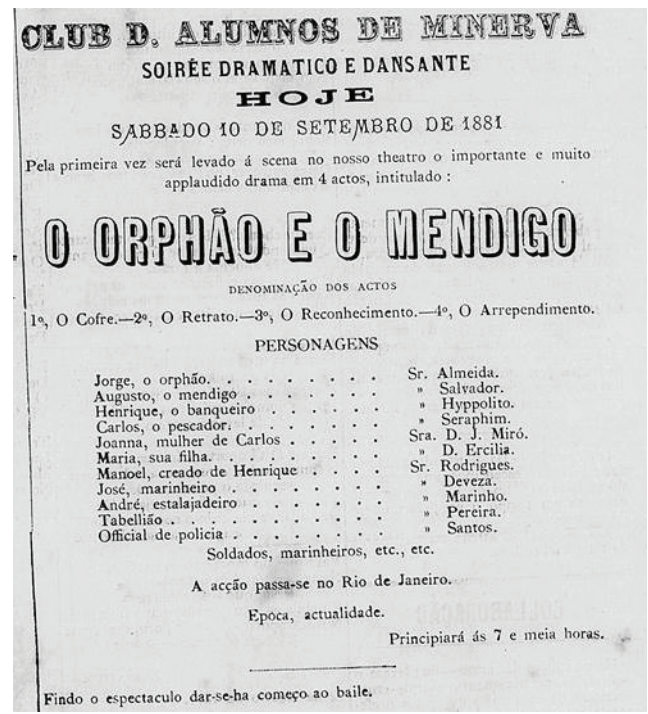

Fonte: $O$ Paladino: orgão do Club D. Alumnos de Minerva.

Rio de Janeiro, ano I, n. 4, 10 set. 1881, p. 4.

\footnotetext{
${ }^{40}$ Estatutos da Recreio Dramatico Juventude Portugueza. Aprovados em junho de 1915. Arquivo Nacional. DP. Cx. IJ6 563, Capítulo XVI, Art. 23.

${ }^{41}$ DORIA, Escragnolle. Teatros de Amadores, op. cit., p. 19.

${ }^{42}$ AZEVEDO, Arthur. O Theatro, op. cit., 16 mar. 1899.

43 O Guarany: órgão do Guarany-Club. Engenho Novo, ano I, n. 1, 1 jan. 1903.

${ }^{44}$ O Scenario: periodico do Club Familiar Gymnasio da Juventude. Rio de Janeiro, Ano I, n. 1, 9 jul. 1881.

45 O Paladino: orgão do Club D. Alumnos de Minerva. Rio de Janeiro, ano I, n. 1, 28 mai. 1881.
} 
Já a Associação Dramatica Particular Gil Vicente previa a apresentação de quatro espetáculos dramáticos anuais,

sendo um em benefício da Caixa de Socorros de D. Pedro V, outro em benefício do Asilo de Inválidos da Pátria e dois em benefício de seus cofres; bem assim os mais espetáculos possíveis em benefício de associaçôes de beneficência, que mais convenientes forem julgados em assembleia geral. ${ }^{46}$

O Grupo Delormista também usava outros espaços para suas festas, como no caso do programa "em benefício a classe comercial" realizado no Teatro Recreio, indicando uma solidariedade aos funcionários do comércio e, possivelmente, a participaçáo desses como associados.

\section{Figura 2. Programa do Grupo Delormista}

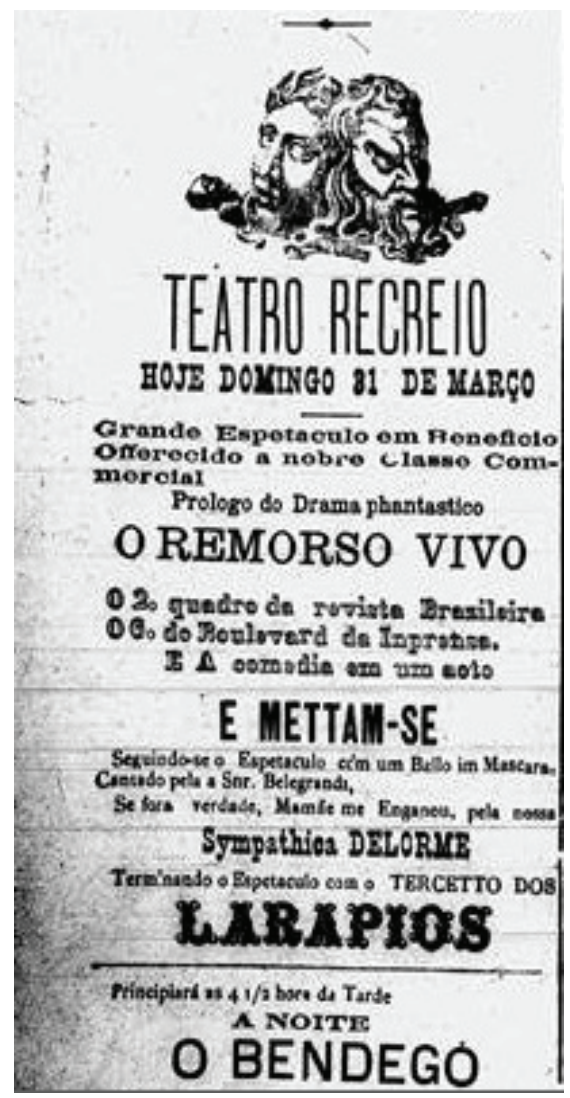

Fonte: $O$ Delormista: orgão consagrado ao theatro fluminense e ao Grupo Delormista.

Rio de Janeiro, ano I, n. 1, 31 mar. 1889, p. 4.

\footnotetext{
${ }^{46}$ Estatutos da Associação Dramatica Particular Gil Vicente. Novembro de 1870. Coleção de Leis do Império do Brasil, 1870, v. 1, pt II, p. 574.
} 
A imagem do programa do Club Dramatico Alumnos de Minerva esclarece que a soirée dramática e dançante de 28 de maio de 1881 seria em benefício dos cofres sociais do próprio clube:

Figura 3. Programa do Club Dramatico Alumnos de Minerva para a soirée dramática e dançante de 28 de maio de 1881

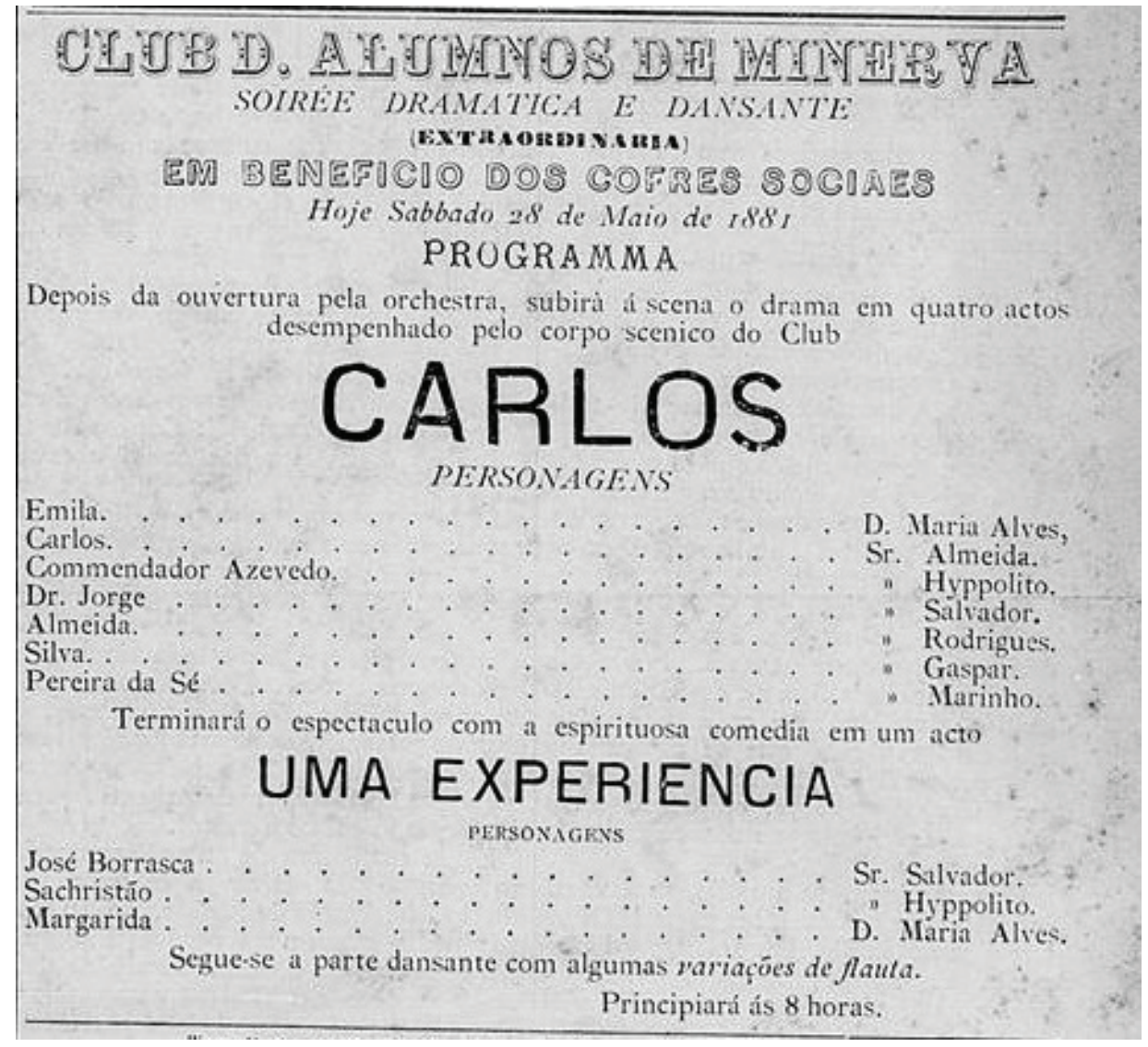

Fonte: $O$ Paladino: orgão do Club Dramatico Alumnos de Minerva.

Rio de Janeiro, ano I, n. 1, 28 mai. 1881.

Diferente dos exemplos anteriores, mas que também se utilizava de espetáculos beneficentes, estava o Grupo Dramatico Teatro Social. Já previsto nos seus estatutos, que deixavam claros seus objetivos de propaganda e ação política, seus sócios determinavam no artigo 7ำ que "os espetáculos em benefício de operários serão concedidos mediante solicitação das comissóes administrativas dos sindicatos a que pertencerem, só sendo atendidos os sindicatos que tenham prestado o seu apoio ao Grupo Dramático Teatro Social". ${ }^{47}$ Ainda havia os benefícios para algum jornal produzido pelo clube ou que o grupo apoiasse. De qualquer

\footnotetext{
${ }^{47}$ Novo Rumo, n. 14, 19 set. 1906. In: VARGAS, Maria Thereza. O Teatro Operário na cidade de São Paulo. São Paulo: Departamento de Informação e Documentação Artísticas, Secretaria Municipal de Cultura, 1980, p. 50-51. Disponível em: <http://www.centrocultural.sp.gov.br/livros/pdfs/teatro.pdf>.
} 
modo, fossem a favor de um operário, um escravo ou órfāos, essas açôes representam uma maneira de atuar política e socialmente no cotidiano, construindo valores demonstrados nesses atos simbólicos.

Mesmo dentro de algumas associaçóes exclusivamente dramáticas, havia uma preocupação com a instrução. Para estas, o teatro tinha uma função pedagógica, porém é necessário observar que a instrução não estava restrita ao palco e ao texto cênico escolhido, mas também em outros espaços de convivência criados nas sedes dessas sociedades. A criação de uma biblioteca é definida nos estatutos como um dos objetivos de grande parte dos associados, ao lado de récitas e saraus dramáticos e juntamente com bailes, conferências, aulas, cursos e matinées para os filhos dos sócios. Os periódicos também comentam sobre a inauguração de uma ou outra biblioteca ou ainda sobre seu acervo, valorizando os títulos ligados ao teatro. ${ }^{48}$ No Club Familiar Gymnasio da Juventude a biblioteca "para recreação dos Srs. membros e suas famílias" foi criada em setembro de 1881, com inauguração marcada para o mês seguinte. ${ }^{49}$

O Euterpe Club oferecia matinées que reuniam uma parte literária e outra musical, além da dramática, em suas apresentaçôes "bastante concorridas" ${ }^{50}$ Com o intuito da instrução ou mesmo de mais uma fonte de renda para os cofres do clube, o Club Familiar Gymnasio da Juventude abriu "matrículas para aulas de desenho, português, música, etc." ${ }^{11}$ Esse clube chegou a "formar um grupo para palestras literárias". 52

Havia, então, uma valorização da leitura, da oratória, da declamação, e isso não estava restrito a determinados bairros ou grupo social, pelo contrário, estava presente em praticamente todas as sociedades dramáticas encontradas. Ainda que houvesse associados analfabetos, o texto teatral impresso, por exemplo, foi escrito para ser lido "em voz alta, vislumbrando um tipo de leitura denominada intensiva, tais textos obedeciam a leis e regras próprias à transmissão oral e comunitária”, como afirma Sílvia Cristina Martins de Souza. Ainda segundo a historiadora, a distância entre o texto representado e o texto impresso não era tão grande,

visto o uso de grifos, itálicos, provérbios e trocadilhos. Tais elementos, por sua vez, são indicativos dos dois tipos de relacionamento que tais textos estabeleciam com seus receptores (o espectador e o ouvinte), da sua dupla circulação (palco e página impressa) e de duas práticas de apropriação (a representação teatral e a leitura). ${ }^{53}$

\footnotetext{
${ }^{48}$ Por exemplo, no Almanack dos Theatros, publicado no Rio de Janeiro para o ano de 1910, o almanaque dedica algumas páginas às sociedades particulares e traça fortes elogios à biblioteca da Sociedade Dramatica Particular Filhos de Talma, p. 45.

${ }^{49}$ O Scenario: periodico do Club Familiar Gymnasio da Juventude. Ano I, n. 4, 18 set. 1881, p. 1.

${ }^{50}$ A Madrugada: periodico litterario e recreativo dedicado ao Euterpe Club. Rio de Janeiro, ano I, n. 1, 11 jan. 1902.

${ }^{51}$ O Scenario: periodico do Club Familiar Gymnasio da Juventude. Ano I, n. 4, 18 set. 1881, p. 3.

${ }^{52}$ O Scenario: periodico do Club Familiar Gymnasio da Juventude. Ano II, n. 7, jun. 1882, p. 1.

${ }^{53}$ SOUZA, Sílvia Cristina Martins de. Do tablado às livrarias: edição e transmissão de textos teatrais no Rio de Janeiro da segunda metade do século XIX. Anais do IV Congresso Internacional de História, Paraná, Universidade Estadual de Maringá, 9 a 11 de setembro de 2009.
} 
As leituras, no entanto, eram diversificadas e não restritas ao gênero dramático. Alguns clubes dramáticos ofereciam aulas de português, inclusive, à noite para que um maior número de sócios pudesse frequentá-las. Além disso, apesar do alto índice de analfabetismo, a população carioca já era majoritariamente alfabetizada. ${ }^{54}$ Em 1890, a população do Rio de Janeiro era na ordem de 522 mil habitantes, dentre os quais 307 mil (58,8\%) declararam saber ler e escrever; em 1906, já havia 818.113 habitantes, dos quais 490 mil (59,8\%) eram alfabetizados; em 1920 , esse percentual subiu para $61,1 \%$ do total da população. ${ }^{55}$

Os programas dos saraus dramáticos, a imprensa teatral e, mais ainda, aquela produzida pelos amadores trazem informaçôes importantes sobre a escolha dos repertórios. Ao analisar as peças escolhidas foi possível constatar a significativa presença de autores portugueses, encenados, inclusive, décadas após a publicação original dos textos teatrais. Entre as possíveis explicaçôes para essa predominância, podemos elencar a facilidade da língua, dispensando traduçóes, e ainda o fácil acesso a esses textos teatrais nas livrarias existentes na cidade, e, talvez, nas próprias bibliotecas nas sedes das sociedades particulares. Alguns desses textos eram representados também no teatro comercial e visavam à pura diversão do público.

Esse trânsito de determinados textos cênicos entre os palcos profissionais e amadores indicam o caráter polissêmico dessas peças, possibilitando diferentes interpretaçóes tanto estéticas quanto morais, ideológicas e/ou políticas. A presença portuguesa no teatro amador se evidencia também nas homenagens a artistas portugueses escolhidos para nomear vários clubes dramáticos, como no caso do Arcadia Dramatica Esther de Carvalho, da Sociedade Dramatica Particular Furtado Coelho, do Club Dramatico Souza Bastos e do Gremio Taborda ou, ainda, nos próprios grupos amadores formados por imigrantes portugueses, como a Real Sociedade Club Gymnastico Portuguez, Recreio Dramatico Juventude Portugueza, entre outros. As digressões de artistas portugueses pelo Brasil e de brasileiros em Lisboa alimentavam e fortaleciam ainda mais esses laços.

No entanto, apesar da presença das peças portuguesas e de outros autores estrangeiros marcarem as escolhas de repertório dessas sociedades particulares, autores brasileiros também eram colocados em cena. Os repertórios dos grupos dramáticos amadores incluíam uma diversidade de textos cênicos: desde as comédias ligeiras e revistas de Arthur Azevedo, França Junior, entre outros, passando pelos melodramas portugueses e os dramas franceses, até as peças de teor social encenadas em diversas línguas nos palcos de operários-atores.

\footnotetext{
${ }^{54}$ MACIEL, Laura Antunes. De "o povo não sabe ler" a uma história dos trabalhadores da palavra. In: MACIEL, Laura Antunes; ALMEIDA, Paulo Roberto de; KHOURY, Yara Maria Aun (Orgs.). Outras histórias: memórias e linguagens. São Paulo, Olho d'água, 2006, p. 283.

${ }_{55}$ DAMAZIO, Sylvia F. Retrato social do Rio de Janeiro na virada do século. Rio de Janeiro: Eduerj, 1996, p. 125-126 apud MACIEL, Laura Antunes. De "o povo não sabe ler" a uma história dos trabalhadores da palavra. In: MACIEL, Laura Antunes; ALMEIDA, Paulo Roberto de; KHOURY, Yara Aun (Orgs.) Outras histórias: memórias e linguagens. op. cit., p. 283.
} 
Para além dos escritores mais conhecidos, localizei amadores que foram também autores de peças teatrais, além de folhetins, poesias, cançóes, sendo também colaboradores e produtores de vários jornais. Assim, muitos sócios participavam nas associaçôes dramáticas amadoras como intelectuais, autores e produtores de textos e espetáculos teatrais, além de atuarem como espectadores ou atores. Essas experiências demonstram, então, o domínio das regras e estilos da cultura letrada por parte dos sócios dos clubes dramáticos amadores, ainda que eles não fossem reconhecidos por críticos e jornalistas dos grandes jornais nem por vários historiadores que contaram a história do teatro brasileiro.

\section{O teatro amador como parte do cotidiano da sociedade carioca}

Fosse através da dança, da música, da literatura, da produção de periódicos ou do teatro, a população carioca se reunia em seus bairros, junto a vizinhos, colegas de trabalho e familiares para, por intermédio de variadas formas de expressáo, lutarem por reconhecimento, maior instrução, melhorias urbanas, sociais ou trabalhistas, travarem um diálogo com as autoridades constituídas ou exercitarem práticas de diversão entre eles próprios e construírem e afirmarem sua cidadania no cotidiano da capital.

Assim, pensar os grupos dramáticos a partir das explicaçóes e interpretaçóes acerca da atuação cotidiana, que expressava uma ação política e social daqueles atores individuais e coletivos, privilegiando suas lógicas cognitivas, vivências e sensibilidades segundo seus próprios códigos culturais, ${ }^{56}$ me parece adequado para o tema abordado. Os sócios das sociedades particulares, assim como seus corpos cênicos, são parte constitutiva de um quadro político, social, econômico e cultural do Rio de Janeiro no período abordado; as escolhas dos espetáculos, os comportamentos e as regras comportamentais e os temas debatidos são uma lente para um momento importante de transformaçáo e das tensóes sociais vividas na capital federal.

O teatro amador parecia se constituir não apenas um agente polemizador e polifônico, mas, por meio de seus diferentes gêneros, públicos e possibilidades, se tornava campo de disputas sociais e espaços de negociação de ideias, onde se pensavam avaliaçôes sobre a realidade cotidiana. Desde as senhoras da haute gomme, passando pelos trabalhadores e imigrantes, as discussôes, fossem eruditas ou operárias, eram polemizadas, tornando os palcos amadores também palcos de debates e conflitos da sociedade carioca no final do século XIX e princípio do XX, espaços onde se constituíam e expressavam sentidos e percepçôes sobre o processo de transformaçáo do Rio de Janeiro, revelando identidades dos diversos grupos que tinham os espetáculos teatrais como parte importante constitutiva do seu cotidiano.

\footnotetext{
${ }^{56}$ GOMES, Ângela de Castro. História, historiografia e Cultura Política no Brasil: algumas reflexôes. In: SOIHET, Rachel; BICALHO, Maria Fernanda; GOUVÊA, Maria de Fátima S. Culturas políticas. Rio de Janeiro: Mauad, 2005, p. 30.
} 


\section{Fontes documentais}

\section{Periódicos}

Almanaque d'O Theatro, ano 1, 1906.

Almanack dos theatros. Rio de Janeiro, 1910.

A Madrugada: periodico litterario e recreativo dedicado ao Euterpe Club. Rio de Janeiro, ano I, n. 1, 11 jan. 1902.

O Scenario: periodico do Club Familiar Gymnasio da Juventude. Ano I, n. 1, 9 jul. 1881, n. 4, 18 set. 1881 e ano II, n. 7, jun. 1882.

O Delormista: orgão consagrado ao theatro fluminense e ao grupo Delormista. Rio de Janeiro, ano I, n. 1, 31 mar. 1889.

O Guarany: órgão do Guarany-Club. Engenho Novo, ano I, n. 1, 1 jan. 1903.

O Paladino: orgão do Club D. Alumnos de Minerva. Rio de Janeiro, ano I, n. 1, 28 mai. 1881 e n. 3, 6 ago. 1881.

Gazeta Suburbana, ano I, n. 2, 22 dez. 1883 e ano II, n. 3, 6 jan. 1884.

Revista da Semana, Rio de Janeiro, 26 jun. 1943.

Novo Rumo, n. 14, 19 set. 1906.

\section{Memórias}

ABREU, Brício de. Esses populares tão conhecidos. Rio de Janeiro: Raposo Carneiro, 1963. AZEVEDO, Arthur. O Theatro, A Noticia, Rio de Janeiro. In: NEVES, Larissa de Oliveira; LEVIN, Orna Messer (Orgs.). O Theatro, crônicas de Arthur Azevedo. Campinas: Editora Unicamp, 2009.

CACCIAGLIA, Mario. Pequena história do teatro no Brasil (quatro séculos de teatro no Brasil). São Paulo: Edusp, 1986.

DAMAZIO, Sylvia F. Retrato social do Rio de Janeiro na virada do século. Rio de Janeiro: Eduerj, 1996, p. 125-126, apud MACIEL, Laura Antunes. De "o povo não sabe ler" a uma história dos trabalhadores da palavra. In: MACIEL, Laura Antunes; ALMEIDA, Paulo Roberto de; KHOURY, Yara Maria Aun (Orgs.). Outras histórias: memórias e linguagens. São Paulo, Olho d'água, 2006.

DORIA, Escragnole. Teatro de amadores. Revista da Semana, Rio de Janeiro, p. 19, 26 jun. 1943. EDMUNDO, Luiz. [1938] O Rio de Janeiro do meu tempo. Brasília: Conselho Editorial do Senado Federal, 2003.

EFEGÊ, Jota. Meninos, eu vi. Rio de Janeiro: Funarte, Instituto Nacional de Música, Divisão de Música Popular, 1985. 
. O cabrocha (Meu companheiro de "farras"). Rio de Janeiro: Casa Leuzinger, 1931.

MARINHO, Henrique. O Theatro Brasileiro (Alguns apontamentos para sua história). Rio de Janeiro: H. Garnier, 1904.

NETO, Coelho. Palestras da tarde. Rio de Janeiro: Livraria Garnier, 1911.

NUNES, Mário. 40 anos de teatro. Rio de Janeiro: SNT, 1956, v. I (1913-1920), v. II (19211925), v. III (1925-1930), v. IV (1931-1935).

PAIXÃO, Múcio da. O Theatro no Brasil (obra póstuma). Rio de Janeiro: Brasília Editora, 1917. RIO, João do. Questão Teatral, 30 de maio de 1909. In: PEIXOTO, Níobe Abreu. João do Rio e o palco: página teatral. São Paulo: Edusp, 2009.

SOUZA, J. Galante de. O Teatro no Brasil. Rio de Janeiro, MEC/Instituto Nacional do Livro, 1960, t. I e II.

TIGRE, Manoel Bastos. Reminiscências. A alegre roda da Colombo e algumas figuras do tempo de antigamente. Brasília: Thesaurus Editora, 1992.

\section{Documentos da polícia}

Estatutos da Sociedade Estudantina Dramatica Luzo-Brasileira. Abril de 1913. Arquivo Nacional. Cx. GIFI 6C 479.

Estatutos do Gremio Recreativo de Ramos. Junho de 1914. Arquivo Nacional. Cx. IJ6 595. Estatutos da Recreio Dramatico Juventude Portugueza. Junho de 1915. Arquivo Nacional. DP. Cx. IJ6 563.

Estatutos da Associação Dramatica Particular Gil Vicente. Novembro de 1870. Coleção de Leis do Império do Brasil, 1870, vol. 1, pt II, p. 574.

\section{Peça teatral}

AZEVEDO, Arthur. O Badejo. In: AZEVEDO, Arthur. Teatro de Artur Azevedo. Rio de Janeiro: Funarte, 2002, v. V.

\section{Referências bibliográficas}

ABREU, Martha. O "crioulo Dudu": participação política e identidade negra nas histórias de um músico cantor (1890-1920). Topoi, v. 11, n. 20, p. 92-113, jan./jun. 2010.

; MARZANO, Andrea Barbosa. Entre palcos e músicas: caminhos de cidadania no início da República. In: CARVALHO, José Murilo; NEVES, Lúcia Maria Bastos Pereira das (Orgs.). Repensando o Brasil do Oitocentos: cidadania, política e liberdade. Rio de Janeiro: Civilização Brasileira, 2009. 
BARROS, Orlando de. Coraçóes de Chocolat: a história da Companhia Negra de Revistas (1926-27). Rio de Janeiro: Livre Expressão, 2005.

BATALHA, Claudio Henrique de Moraes. A geografia associativa: associaçóes operárias, protesto e espaço urbano no Rio de Janeiro da Primeira República. In: AZEVEDO, Elciene; CANO, Jefferson; CUNHA, Maria Clementina Pereira; CHALHOUB, Sidney (Orgs.). Trabalhadores na cidade: cotidiano e cultura no Rio de Janeiro e em São Paulo, séculos XIX e XX. Campinas: Editora da Unicamp, 2009.

FONSECA, Vitor Manoel Marques da. No gozo dos direitos civis: associativismo no Rio de Janeiro, 1903-1916. Rio de Janeiro: Arquivo Nacional/Niterói: Muiraquitã, 2008.

MACIEL, Laura Antunes. Cultura letrada, intelectuais e memórias populares. In: ENGEL, Magali Gouveia; CORRÊA, Maria Letícia; SANTOS, Ricardo Augusto dos (Orgs.). Os intelectuais e a cidade: séculos XIX e XX. Rio de Janeiro: Contra Capa, 2012.

De “o povo não sabe ler" a uma história dos trabalhadores da palavra. In: MACIEL, Laura Antunes; ALMEIDA, Paulo Roberto de; KHOURY, Yara Maria Aun (Orgs.). Outras histórias: memórias e linguagens. São Paulo: Olho d'água, 2006.

MENDONÇA, Leandro Climaco Almeida de Melo. Nas margens: experiências de suburbanos com periodismo no Rio de Janeiro, 1880-1920. Dissertação (mestrado em História) Programa de Pós-graduação em História, Universidade Federal Fluminense, Niterói, 2011. PENNA-FRANCA, Luciana. Teatro amador: a cena carioca muito além dos arrabaldes. Editora Alameda: São Paulo, 2016.

PEREIRA, Leonardo Affonso de Miranda. Os Anjos da Meia-noite: trabalhadores, lazer e direitos no Rio de Janeiro da Primeira República. Tempo, v. 19, n. 35, p. 97-116, 2013.

- Do Congo ao tango: associativismo, lazer e identidades entre os afro-portenhos na segunda metade do século XIX. Revista Mundos do Trabalho, v. 3, n. 6, p. 31-35, jul./dez. 2011. PESTANA, Marco Marques. Da zona sul ao subúrbio: o mapa da festa. Por uma reconstrução holística do cotidiano dos trabalhadores cariocas, 1900-1920. Revista Mundos do Trabalho, v. 2, n. 4, ago./dez. 2010.

ROCHA, Oswaldo Porto. A era das demoliçôes: cidade do Rio de Janeiro: 1870-1920. Rio de Janeiro: Secretaria Municipal de Cultura, Dep. Geral de Doc. e Inf. Cultural, Divisão de Editoração, 1995.

SIQUEIRA, Uassyr de. Clubes recreativos: organização para o lazer. In: AZEVEDO, Elciene; CANO, Jefferson; CUNHA, Maria Clementina Pereira; CHALHOUB, Sidney (Orgs.). Trabalhadores na cidade: cotidiano e cultura no Rio de Janeiro e em São Paulo, séculos XIX e XX. Campinas: Editora da Unicamp, 2009.

SOUZA, Sílvia Cristina Martins de. Do tablado às livrarias: edição e transmissão de textos teatrais no Rio de Janeiro da segunda metade do século XIX. Anais do IV Congresso Internacional de História, Paraná, Universidade Estadual de Maringá, 9 a 11 de setembro de 2009. 
THOMPSON, E. P. Folclore, antropologia e história social. In: NEGRO, Antonio Luigi; SILVA, Sergio (Orgs.). As peculiaridades dos ingleses e outros artigos. Campinas: Editora da Unicamp, 2001, p. 231-235. 